\title{
Productivity and economic indicators of sweet maize silage treated with diazotrophic bacteria and thiamine
}

\author{
Productividad e indicadores económicos de ensilaje de maíz dulce \\ tratado con bacterias diazotróficas y tiamina
}

Vendruscolo EP, Campos LFC, Oliveira PR, Seleguini A, Lima SF. Productivity and economic indicators of sweet maize silage treated with diazotrophic bacteria and thiamine. Rev Colombiana Cienc Anim. Recia. 2020; 12(1):e738. DOI: https://doi.org/10.24188/recia.v12.n1.2020.738

Universidad de Sucre, Colombia

Los autores permiten a RECIA reimprimir el material publicado en él. En caso de que un autor quiera traducir o usar una publicación parcial o completa de nuestro Diario, el autor debe obtener un permiso por escrito del editor de la revista.

Copyright (C) 2020. El (los) autor (es), Revista Colombiana de Ciencia Animal - RECIA. 2020. Este es un artículo de acceso abierto distribuido bajo los términos de Creative Commons Attribution 4.0 (https://creativecommons.org/licenses/by-nc-sa/4.0/), El uso, distribución o reproducción está permitido, siempre que se acrediten al autor original y al propietario del copyright y que se cite la publicación original en esta revista, de acuerdo con la práctica académica aceptada. No se permite el uso, distribución o reproducción que no cumpla con estos términos. 


\title{
Productivity and economic indicators of sweet maize silage treated with diazotrophic bacteria and thiamine
}

\author{
Productividad e indicadores económicos de ensilaje de maíz dulce tratado con bacterias \\ diazotróficas y tiamina
}

Eduardo Pradi Vendruscolo, ${ }^{*}$ Ph.D.

DOI: https://doi.org/10.24188/recia.v12.n1.2020.738

Mato Grosso do Sul State University, Cassilândia, Brazil.

agrovendruscolo@gmail.com

(D) https://orcid.org/0000-0002-3404-8534

Luiz Fernandes Cardoso Campos, Ph.D.

Goiás State University, São Luís dos Montes Belos, Brazil.

luizfernandescampos@hotmail.com

(i) https://orcid.org/0000-0001-5171-5194

Paulo Ricardo de Oliveira, Agronomy.

Goiás Federal University, Goiânia, Brazil.

pauloagronomy@gmail.com

(iD) https://orcid.org/0000-0001-6094-743X

Alexsander Seleguini, Ph.D.

Triângulo Mineiro Federal University, Iturama, Brazil.

aseleguini@gmail.com

(iD) https://orcid.org/0000-0002-5762-9278

Sebastião Ferreira de Lima, Ph.D.

Mato Grosso do Sul Federal University, Chapadão do Sul, Brazil.

sebastiao.lima@ufms.br

(iD) https://orcid.org/0000-0001-5693-912X

Recepción: 13 Noviembre 2019 Aprobación: 01 Marzo 2020 Publicación: 13 Marzo 2020

\begin{abstract}
Objective. Evaluate the productivity, sweet maize plants characteristics, crude protein and economic indicators of the production of sweet maize silage inoculated with Azospirillum brasilense and thiamine as seed treatment (0; 15; 30; $45 \mathrm{mg} \mathrm{kg}^{-1}$ ). Material and Methods. Biometric characteristics, productivity, crude protein content were evaluated, and the total operational cost structure was used to determine the economic indexes of a productive cycle. Results. It was observed that treatments with isolated or combined application of $A$. brasilense and thiamine did not affect the plant height, stem diameter, fresh and dry mass productivity and crude protein contents of sweet maize plants. However, the inoculation with $A$. brasilense increased in $24.36 \%, 24.36 \%, 53.15 \%$ and $10.47 \%$, the productivity of fresh matter, gross revenue, operating profit and the profitability index, respectively, compared to the control treatment. Even with different responses, all treatments resulted in positive profitability indices, indicating the appropriate economic return with this activity. Conclusion. It was concluded that A. brasilense and thiamine applied as seed treatment do not significantly affect sweet maize plants development and composition; treatments influenced the economical indexes, and the isolated application of $A$. brasilense resulted in higher earnings; thiamine isolated application as seed treatment can be used as an alternative for improvement of economical gains.
\end{abstract}

Keywords: Zea mays convar saccharata var. Rugose; Azospirillum brasiliense; vitamin B1; nitrogen biological fixation; biostimulant.

\section{RESUMEN}

Objetivo. Evaluar la productividad, las características de las plantas de maíz dulce, la proteína cruda y los indicadores económicos de la producción de ensilaje de maíz dulce inoculado con Azospirillum brasilense y tiamina como tratamiento de semillas $\left(0 ; 15 ; 30 ; 45 \mathrm{mg} \mathrm{kg}^{-1}\right)$. Materiales y métodos. Se evaluaron las características biométricas, la productividad, 
el contenido de proteína cruda y la estructura de costos operativos totales para determinar los índices económicos de un ciclo productivo. Resultados. Se observó que los tratamientos con aplicación aislada o combinada de $A$. brasilense y tiamina no afectaron la altura de la planta, el diámetro del tallo, la productividad en masa fresca y seca y el contenido de proteína cruda de las plantas de maíz dulce. Sin embargo, la inoculación con A. brasilense aumentó en 24.36\%, $24.36 \%, 53.15 \%$ y 10.47\%, la productividad de la materia fresca, los ingresos brutos, el beneficio operativo y el índice de rentabilidad, respectivamente, en comparación con el tratamiento de control. Incluso con diferentes respuestas, todos los tratamientos dieron como resultado índices de rentabilidad positivos, lo que indica el rendimiento económico apropiado con esta actividad. Conclusiones. Se concluyó que $A$. brasilense y tiamina aplicadas como tratamiento de semillas no afectan significativamente el desarrollo y la composición de las plantas de maíz dulce; los tratamientos influyeron en los índices económicos, y la aplicación aislada de A. brasilense resultó en mayores ganancias; La aplicación aislada de tiamina como tratamiento de semillas puede usarse como una alternativa para mejorar las ganancias económicas.

Palabras clave: Zea mays convar; saccharata var; rugosa; Azospirillum brasiliense; vitamina B1; fijación biológica de nitrógeno; bioestimulante.

\section{INTRODUCTION}

The exploration of different crops in a single property reduces the effect of the price oscillation paid to the farmer, especially in small and medium farms, where higher value crops should be preferred to optimize the area under cultivation. Among several species, sweet maize (Zea mays convar saccharata var. rugosa) is a crop that can be used with positive rates of profitability (1).

In contrast to the conventional maize used for grain production, sweet maize demands greater investments in manual harvesting, since its harvest is carried out when ears still in the field, with high moisture contents in the grains. This characteristic of management results in residual green plants in the field after ears harvest. When preparing the soil for planting a new crop, these plants are incorporated into the soil as green manure or kept as straw on the soil surface. It is also observed the possibility of the utilization of these plants as raw material for silage production (2), generating extra income for the producer. However, there are no scientific research about this economical thematic.

In addition to the high value crops exploration, the possibility of using new technologies, aimed at increasing the quality of the material produced, can be considered. In this perspective, it is observed the introduction of diazotrophic bacteria, which can perform the biological fixation of atmospheric nitrogen in grasses, through the enzyme nitrogenase (3), culminating in positive growth effect on maize plants, for example (4). It is also observed that the inoculation with these bacteria is a low-cost technique, when its participation in the total operational cost of production is verified $(5,6)$.

Besides the diazotrophic bacteria, in recent years, compounds of a protective and biostimulating action has also been introduced. These compounds are used to maintain or increase the quality of the products. Vitamins, especially thiamine, still poorly explored in this field, although studies have shown that, these compounds have activities related to the production of secondary metabolites and even the expression of genes which act to protect plants (7). Also, the exogenous application of thiamine increases nutrient and energy reserves $(8,9)$, which can be used for the development and maintenance of plant metabolic activity during periods of stress (10).

Although both technologies have positive effects on the cultures to which were applied, it was worked with the hypothesis that there is an interaction between them, due to their characteristics, endophytic presence of the bacterium and the protective action of the vitamin. The objective of this study was to evaluate the productivity, sweet maize plants characteristics, crude protein and economic indicators of the production of sweet maize silage inoculated with Azospirillum brasilense and thiamine as seed treatment

\section{MATERIAL AND METHODS}

Experimental conditions. The study was carried out in the experimental area of the Agronomy School, at the Federal University of Goiás, located in the city of Goiânia, Goiás State, Brazil (latitude $16^{\circ} 40^{\prime}$ S, longitude $49^{\circ} 15^{\prime}$ W and altitude of $750 \mathrm{~m}$ ). This region has an $A w$ climate, according to KÖPPEN-GEIGER classification (11). The soil present in the experimental area was classified as Latossolo Vermelho distroférrico (12) and through laboratory chemical analysis (13)

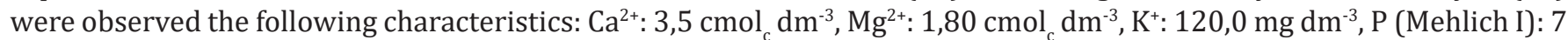
mg dm${ }^{-3}$, Organic matter: $16 \mathrm{~g} \mathrm{~kg}^{-3}, \mathrm{Al}^{3+}: 0,0 \mathrm{cmol}_{\mathrm{c}} \mathrm{dm}^{-3}, \mathrm{H}+\mathrm{Al}: 1,1 \mathrm{cmol}_{\mathrm{c}} \mathrm{dm}^{-3}, \mathrm{pH}\left(\mathrm{CaCl}_{2}\right): 6,4, \mathrm{CTC}: 6.71 \mathrm{cmolc} \mathrm{dm}^{-3}, \mathrm{~V}: 84 \%$. 
The granulometric analysis of the soil presented $450 \mathrm{~g} \mathrm{~kg}^{-1}$ of clay in the $0-0.2 \mathrm{~m}$ layer.

The climatic records of temperature and relative humidity, which occurred during the experiment conduction, were obtained from an evaporimetric station installed $100 \mathrm{~m}$ from the experimental area (Figure 1).

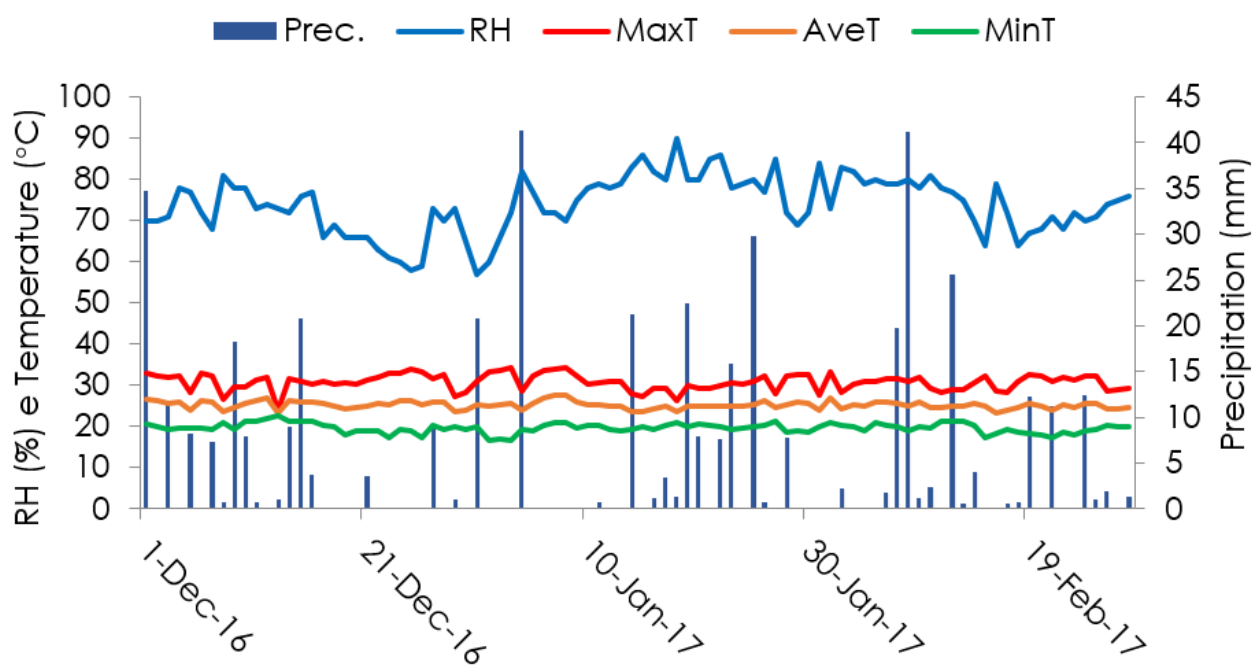

Figure 1. Climatic conditions of, precipitation (Prec.), relative air humidity (RH) and maximum (MaxT), average (AveT) and minimum (MinT) temperature during the conduction of the experiment.

Experimental desing. It was used a randomized block design, in a $2 x 4$ factorial, totaling eight treatments, corresponding to the combination between inoculation with $10 \mathrm{~mL}$ of Azospirillum brasilense $\mathrm{kg}^{-1}$ seeds (with or without) and treatment with different doses of thiamine via seed $\left(0,15,30\right.$ e $\left.45 \mathrm{mg} \mathrm{kg}^{-1}\right)$, in three repetitions. Each experimental plot consisted of an area of $10.00 \mathrm{~m}^{2}$, five lines of $4.00 \mathrm{~m}$ in length spaced $0.50 \mathrm{~m}$ apart.

Conduction of the experiment. The spontaneous plants in the area were desiccated with glyphosate-based herbicide (48\% i.e.) one week before sowing. On December $1^{\text {st }}$ of 2016 sweet maize (cv. BRS Vivi) was sowed in a planting space of $0.30 \times 0.50 \mathrm{~m}$, between plants and between lines, respectively, totaling a population of 66,700 plants ha-1.

For cover fertilization, $50 \mathrm{~kg} \mathrm{ha}^{-1} \mathrm{~N}$ at 15 and 45 days after sowing were applied (urea 46\% N). A single dose of $\mathrm{KCl}$ ( $60 \%$ $\mathrm{K}$ ), equivalent to $40 \mathrm{~kg} \mathrm{ha}^{-1} \mathrm{~K}_{2} \mathrm{O}$, was applied together with the second nitrogen application. During the cycle, a single application of insecticide based on LAMBDA-CIALOTRIN (50\% a.i.) was carried out to control Spodoptera frugiperda at 43 days after sowing.

Evaluation. When was observed a 30\% humidity content in plants (R4 stage), the morphological components of plant height, stem diameter, fresh and dry mass productivity, dry mass content and crude protein content in the dry mass were evaluated. The plant height was measured with a measuring tape, measuring the height from the plant lap to the last leaf insertion, the stem diameter was measured with a digital caliper, measuring the plant stem at $10 \mathrm{~cm}$ above of the soil surface, both determinations made in ten plants per plot.

For determination of the fresh weight productivity, it was carried a manual cutting of ten plants per plot, $20 \mathrm{~cm}$ from the ground and then chopped in a stationary shredder with an average particle size of two centimeters, thus obtaining the whole plant forage at the silage point. After plants harvest, they were immediately weighed to determine the green mass yield. A portion of the homogenous and representative crushed mass was packed in paper bags, weighed and dried in a forced air oven at $65^{\circ} \mathrm{C}$ until a constant mass was obtained to determine the dry mass. Productivity was estimated for Mg $\mathrm{ha}^{-1}$. The crude protein content was determined by the Kjeldahl method (nitrogen content (NC) x 6.25), according to the methodology described by Silva and Queiroz (14).

To determine the production cost of sweet maize silage, the total operational cost (TOC) structure was used (15). The TOC is obtained by the sum of the expenses with interest of cost, depreciation, other expenses and the effective operational cost (EOC), which is composed of the expenses of the operations and inputs used. 
The economic analysis was proceeded considering the different treatments as commercial crops. However, only activities related to silage harvesting, such as harvesting, grinding and other costs related to social charges, technical assistance, production insurance, and financial charges were considered.

To obtain the average prices received by the producers, the commercialization values of silage in the region of Goiânia were taken into account as soon as the experiment was finished. The average price of conventional maize silage in this period was USD $19.89 \mathrm{Mg}^{-1}$. For calculation purposes, this value was used in the present work. The conversion to US dollars (USD) was made using the quotation in effect on February 11, 2020 (USD $1.00=\mathrm{R} \$ 4,32$ ).

Labor costs were calculated through the index generated by the need for manual operations for each operation, obtained in men/day (MD), then multiplied by the average value of labor force in the region in the year 2017 (USD 16.20). For inputs, the cost was calculated based on the average product value in the region, obtained from agricultural trading companies. To obtain direct social charges, technical assistance, financial charges and production insurance, rates of $33.0 \%, 2.00 \%, 12.5 \%$ and $4.2 \%$, respectively, were considered for EOC (16).

To determine the profitability of each treatment, were calculated (15): a) gross revenue, obtained between the quantity produced ( $\left.\mathrm{Mg} \mathrm{ha}^{-1}\right)$ and the average price received by the producer in the period from January to May of 2017; b) operating profit, such as the difference between gross revenue and total operating cost; c) profitability index, understood as the proportion of the gross revenue that represents the final amount after covering the total production operational cost; d) equilibrium price, given at a given level of total production operational cost, as the minimum price required to be covered to cover the TOC, taking into account the average productivity obtained by the producer; e) equilibrium productivity, given at a level of total production operational cost, as the minimum productivity required to cover TOC.

Statistical analysis. The data related to the morphological, productive and protein content were submitted to analysis of variance, and the mean values were compared by the Tukey test at $5 \%$ of significance.

\section{RESULTS}

It was observed that treatments with isolated or combined application of $A$. brasilense and thiamine did not affect the plant height, stem diameter, fresh and dry mass productivity and crude protein contents of sweet maize plants (Table 1).

Table 1. Plant height, stem diameter, fresh mass productivity, dry mass productivity, dry mass content and crude protein of silage produced from sweet maize plants treated with $A$. brasilense and thiamine.

\begin{tabular}{|c|c|c|c|c|c|c|}
\hline A. brasilense & Plant height (m) & Stem diameter $(\mathrm{mm})$ & $\begin{array}{c}\text { Fresh mass } \\
\text { productivity } \\
\left(\mathrm{Mg} \mathrm{ha}^{-1}\right)\end{array}$ & $\begin{array}{c}\text { Dry mass } \\
\text { productivity } \\
\left(\mathrm{Mg} \mathrm{ha}^{-1}\right)\end{array}$ & Dry mass content \% & Crude protein \% \\
\hline With & $2.00 \mathrm{a}$ & $20.50 a$ & $24.38 \mathrm{a}$ & $7.59 a$ & $31.26 \mathrm{a}$ & $5.97 a$ \\
\hline Without & $1.97 \mathrm{a}$ & $19.96 a$ & $24.77 a$ & $7.94 a$ & $32.06 \mathrm{a}$ & $5.53 a$ \\
\hline LSD & 0.06 & 1.05 & 3.60 & 0.99 & 1.36 & 1.07 \\
\hline \multicolumn{7}{|c|}{ Thiamine (mg kg-1) } \\
\hline 0 & 1.99 & 20.11 & 25.39 & 7.96 & 31.78 & 5.89 \\
\hline 15 & 1.99 & 20.26 & 22.23 & 7.16 & 31.70 & 5.56 \\
\hline 30 & 1.98 & 20.61 & 24.61 & 7.75 & 31.61 & 5.99 \\
\hline 45 & 1.98 & 19.94 & 26.07 & 8.16 & 31.53 & 5.57 \\
\hline L.R. & ns & ns & ns & ns & ns & ns \\
\hline $\mathrm{CV} \%$ & 3.54 & 5.91 & 16.75 & 14.59 & 4.90 & 21.23 \\
\hline
\end{tabular}

Same letters in a column indicate means are not significantly different at $\mathrm{p}<0.05$ by Tukey test. L.R. = linear regression; Q.R. = quadratic regression; LSD = least significant difference; $\mathrm{CV}=$ coefficient of variation.

Considering the production of silage as an extra product obtained by the use of sweet maize plants after ears harvest, a total operating cost of USD 228.36 was obtained (Table 2). This amount was composed of 5.71\% for mechanized operations, $60.21 \%$ for manual operations and $34.08 \%$ for other costs. The large participation of manual operations over production costs is due to the high demand for labor to harvest the plants. 
Table 2. Estimated total operational cost for silage produced from sweet maize plants treated with A. brasilense and thiamine in $10000 \mathrm{~m}^{2}$.

\begin{tabular}{|c|c|c|c|c|}
\hline Description & Specification & Quantity & Unit value (USD) & Total (USD) \\
\hline \multicolumn{5}{|l|}{ A - Mechanized operations } \\
\hline Grinding (TL 70+ forage shredder) & $\mathrm{MH}$ & 0.60 & 20.49 & 12.29 \\
\hline SUBTOTAL A & & & & 12.29 \\
\hline \multicolumn{5}{|l|}{ B - Manual operations } \\
\hline Harvesting and plants milling & MD & 8.00 & 16.20 & 129.63 \\
\hline SUBTOTAL B & & & & 129.63 \\
\hline Effective operational costs (EOC) & & & & 141.92 \\
\hline C - Direct social charges & & & & 46.83 \\
\hline D - Technical assistance & & & & 2.84 \\
\hline E - Financial charges & & & & 17.74 \\
\hline F - Production Insurance & & & & 5.96 \\
\hline Total operating costs (TOC) & & & & 215.30 \\
\hline
\end{tabular}

Considering the treatments separately, it was verified that $A$. brasilense and thiamine did not significantly interfere in production costs and did not reach a $1.00 \%$ participation over the total operational costs of silage production. The maximum increase observed was the application of $A$. brasilense, which raised costs by USD 1.49 ha $^{-1}$ (Table 3).

Table 3. Participation of the cost variation factors over the total operating cost for silage produced from sweet maize plants treated with $A$. brasilense and thiamine.

\begin{tabular}{|c|c|c|c|c|c|c|}
\hline \multirow{2}{*}{ Treatments } & \multicolumn{2}{|c|}{ A. brasilense } & \multicolumn{2}{|c|}{ Thiamine } & \multirow{2}{*}{ TOC increase (\%) } & \multirow{2}{*}{$\begin{array}{c}\text { Final TOC } \\
\text { (USD) }\end{array}$} \\
\hline & Qty. $\left(1\right.$ ha $\left.^{-1}\right)$ & Value (USD) & Qty $\left(\mathrm{g} \mathrm{ha}^{-1}\right)$ & Value (USD) & & \\
\hline Control & 0.00 & 0,00 & 0.00 & 0,000000 & 0,00 & 215.30 \\
\hline Th at $15 \mathrm{mg} \mathrm{L}^{-1}$ & 0.00 & 0,00 & 0,11 & 0,000019 & 0,00 & 215.30 \\
\hline Th at $30 \mathrm{mg} \mathrm{L}^{-1}$ & 0.00 & 0.00 & 0.21 & 0.000058 & 0.00 & 215.30 \\
\hline Th at $45 \mathrm{mg} \mathrm{L}^{-1}$ & 0.00 & 0.00 & 0.32 & 0.000039 & 0.00 & 215.30 \\
\hline Az. & 0.07 & 1.49 & 0.00 & 0.000000 & 0.69 & 216.78 \\
\hline $\mathrm{Az}+\mathrm{Th}$ at $15 \mathrm{mg} \mathrm{L}^{-1}$ & 0.07 & 1.49 & 0.11 & 0.000019 & 0.69 & 216.78 \\
\hline $\mathrm{Az}+\mathrm{Th}$ at $30 \mathrm{mg} \mathrm{L}^{-1}$ & 0.07 & 1.49 & 0.21 & 0.000058 & 0.69 & 216.78 \\
\hline $\mathrm{Az}+\mathrm{Th}$ at $45 \mathrm{mg} \mathrm{L}^{-1}$ & 0.07 & 1.49 & 0.32 & 0.000039 & 0.69 & 216.78 \\
\hline
\end{tabular}

It was observed that the economic indices followed the fresh matter productivity trend (Figure 2). In this sense, the utilization of $A$. brasilense increased in $24.36 \%, 24.36 \%, 53.15 \%$ and $10.47 \%$, the productivity of fresh matter, gross revenue, operating profit and the profitability index, respectively, compared to the control treatment. In contrast, the combined treatment of $A$. brasilense and thiamine, at $15 \mathrm{mg} \mathrm{L}^{-1}$, was the worst treatment, reducing the same variables in $8.74 \%, 8.74 \%, 20.07 \%$ and $5.61 \%$, respectively.

The equilibrium productivity was unchanged by the use of thiamine and was raised by about $0.006 \%$ by the seeds inoculation with $A$. brasilense (Table 4). The highest equilibrium price was obtained with the treatment consisting of the treatment with $A$. brasilense and thiamine at a dose of $15 \mathrm{mg} \mathrm{L}^{-1}$, which increased the variable by $10.27 \%$ in relation to the control treatment. However, there was a greater decrease in the equilibrium price, about $19.08 \%$, when isolated inoculation was carried out with $A$. brasilense (Table 4). This indicates that the inoculation with $A$. brasilense reduces the effects of the oscillation of the values paid by the silage, giving more security to the producer. 

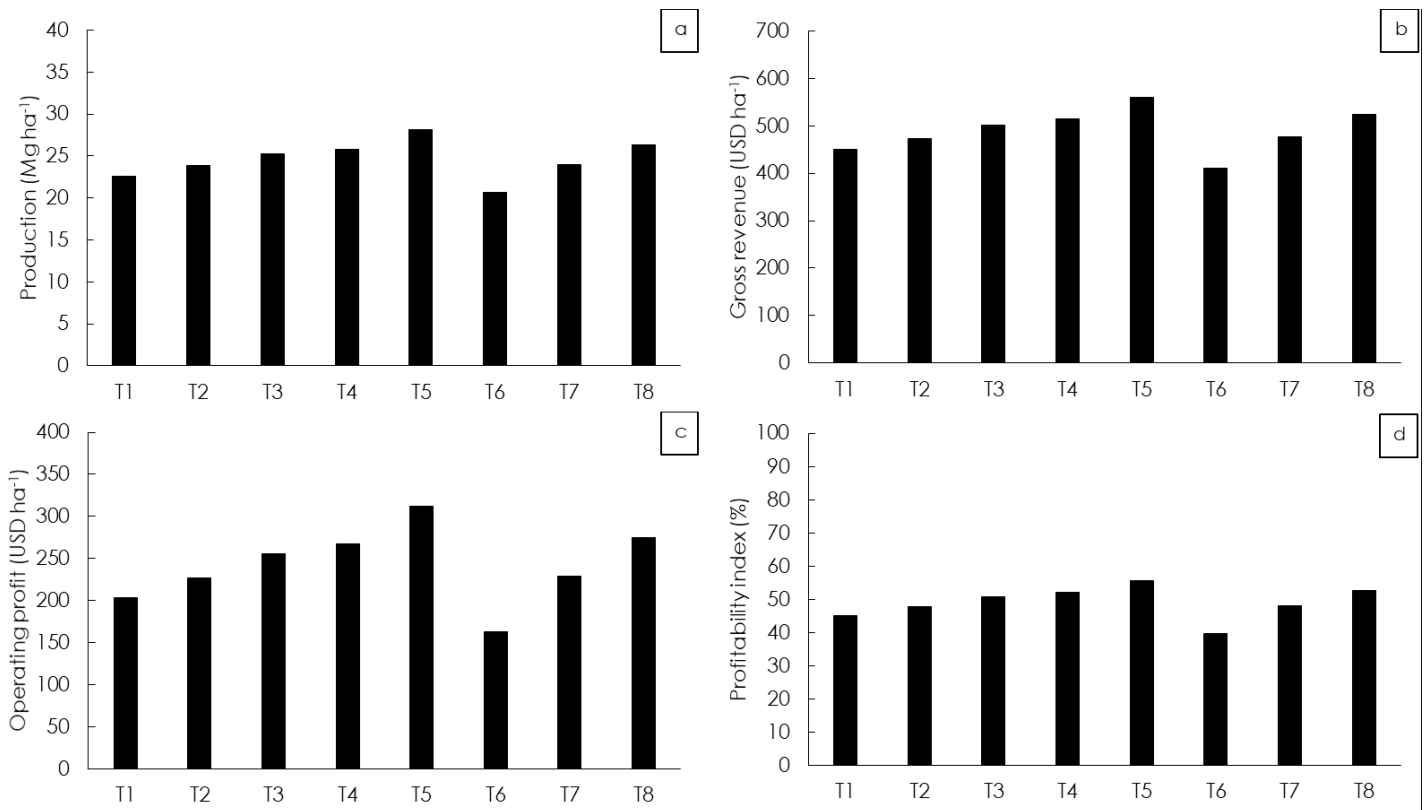

Figure 2. Productivity (a), gross revenue (b), operating profit (c) and profitability index (d) of silage produced from sweet maize plants treated with $A$. brasilense and thiamine. T1 = control; T2 = thiamine at $15 \mathrm{mg} \mathrm{L}^{-1}$; T3 = thiamine at $30 \mathrm{mg} \mathrm{L}^{-1}$; $\mathrm{T} 4=$ thiamine at $45 \mathrm{mg} \mathrm{L}^{-1} ; \mathrm{T} 5=$ A. brasilense; $\mathrm{T} 6=$ A. brasilense + thiamine at $15 \mathrm{mg} \mathrm{L}^{-1} ; \mathrm{T} 7=$ A. brasilense + thiamine at $30 \mathrm{mg}$ $\mathrm{L}^{-1} ; \mathrm{T} 8=$ A. brasilense + thiamine at $45 \mathrm{mg} \mathrm{L}^{-1}$.

Table 4. Equilibrium productivity and equilibrium price for silage produced from sweet maize plants treated with $A$. brasilense and thiamine.

\begin{tabular}{ccc} 
Treatments & Equilibrium productivity $\left(\mathbf{M g ~ h a}^{-1}\right)$ & ${\left.\text { Equilibrium price (USD } \mathbf{M g}^{-1}\right)}$ \\
\hline Control & 2.87 & 9.51 \\
Th at $15 \mathrm{mg} \mathrm{L}^{-1}$ & 2.87 & 9.04 \\
Th at $30 \mathrm{mg} \mathrm{L}^{-1}$ & 2.87 & 8.53 \\
Th at $45 \mathrm{mg} \mathrm{L}^{-1}$ & 2.87 & 7.70 \\
Az. & 2.89 & 10.50 \\
Az + Th at $15 \mathrm{mg} \mathrm{L}^{-1}$ & 2.89 & 9.04 \\
Az + Th at $30 \mathrm{mg} \mathrm{L}^{-1}$ & 2.89 & 8.24 \\
Az + Th at $45 \mathrm{mg} \mathrm{L}^{-1}$ & 2.89 &
\end{tabular}

\section{DISCUSSION}

The non-significant results observed for the biometric and productive characteristics (Table 1) corroborate other studies, in which the effectiveness of inoculation with Azospirillum bacteria on the biometric characteristics of maize plants was not observed when compared to the control treatment $(17,18)$. It was also verified that the response of the maize plants to the inoculation is related to the genotype utilized since some materials present positive responses to shoot development, whereas others present an increase in the reproductive characteristics (19).

In studies about inoculation with $A$. brasilense on corn production it was verified that its use represents a factor of little expressive participation on the operational cost of production $(5,6)$. However, in these same studies, the lack of response of the crop or even the variability of the effect in different culture conditions was verified. 
In this sense, the positive results obtained for productivity of fresh matter, gross revenue, operating profit and the profitability index are related to the action of bacteria and their potential for the biological fixation of atmospheric nitrogen (3). This element is essential for the proper plant's development, as it participates in protein synthesis and photosynthetic activity, directly influencing the energy reserves accumulation in plant organs (10). The negative interaction between inoculation with $A$. brasilense and the application of thiamine as seed treatment is attributed to the protective effect triggered by the presence of the vitamin. Thiamine acts as a production inducer of secondary metabolites, responsible for the plant's protection against harmful action of biotic and abiotic factors $(7 ; 9 ; 23 ; 24)$. Thus, the presence of larger amounts of the vitamin may have increased the production of reactive oxygen species, as well as led to activation of genes related to the plants protection, as in the case of vine (7), culminating in lower plants development, due to the reaction to the presence of the endophytic bacteria. The signaling of a possible infection may also have caused the mobilization of reserves, once it is used in the plant's development (10).

It was also observed that the increase of thiamine doses, regardless of the presence or absence of $A$. brasilense, caused a tendency to increase the variables studied. This response to the application of the vitamin is related to its biostimulating character, increasing nutrient contents in the plants organs (9) and, consequently, favoring the development of the tissues, as verified for the mustard crop (25), quinoa (24) and common beans (26).

The means obtained for plant height were similar to those observed for different maize hybrids grown for silage production (20). For the same hybrids, it was observed that the average dry mass productivity per area, when the contribution of the ears was disregarded (7.12 $\mathrm{Mg} \mathrm{ha}^{-1}$ ), was close to that obtained for sweet maize (7.77 $\mathrm{Mg}^{-1}$ ). However, crude protein levels are lower than those observed in other studies $(21,22)$, result that is probably related to the cultivar characteristics, since absence of ears does not seem to significantly affect the protein content of the silage (27).

Despite the studies aimed at obtaining economic indexes for the maize crop and the effects of the inoculation of diazotrophic bacteria on the economic indexes of its production, no studies about the influence of thiamine on these same indexes were found. Thus, in possession of the results, the vitamin potential for use in crops of economic interest is verified, as a low cost alternative and with the capacity to increase economic gains. This can be seen for the sweet corn crop, for which a positive effect of the application of thiamine on the production and consequently on the monetary return on the sale of the product was verified $(28,29)$.

Given what was observed in this study, it is important to carry out studies aiming to obtain the profitability indexes for techniques used in the commercial interest species production. In some cases, it is possible that even in the absence of statistical differences, changes in the economic variables can occur. This can be used to define the feasibility of implementing a technique or a product application to improve the production system conditions.

In conclusions $A$. brasilense and thiamine applied as seed treatment do not significantly affect sweet maize plants development and composition. Treatments influenced the economical indexes, and the isolated application of $A$. brasilense resulted in higher earnings. Thiamine isolated application as seed treatment can be used as an alternative for improvement of economical gains. In addition, the low cost of obtaining and using the studied products, makes their use in agricultural production feasible, making them promising technologies that demand more studies.

\section{Conflict of interest}

The authors expressed that there is no conflict of interest in this publication.

\section{REFERENCES}

1. Jesus AA, Lima SF, Vendruscolo EP, Alvarez RCF, Contardi LM. Análise econômica da produção do milho doce cultivado com aplicação de bioestimulante via semente. Revista Facultad de Agronomía. 2016; 115(2):119-127. URL Available in: http://revista.agro.unlp.edu.ar/index.php/revagro/article/view/287

2. Santos DC, Santos MVF, Farias I, Dias FM, Lira MA. Desempenho produtivo de vacas $5 / 8$ Holando/Zebu alimentadas com diferentes cultivares de palma forrageira. Opuntia Nopalea. Rev Bras de Zootec. 2001; 30(1):12-17. http:// dx.doi.org/10.1590/S1516-35982001000100003 
3. Hungria M. Inoculação com Azospirillum brasilense: inovação em rendimento a baixo custo. Brazil: Embrapa Soja. 2011. Available in: https://www.infoteca.cnptia.embrapa.br/infoteca/handle/doc/879471

4. Longhini VZ, Souza WCR, Andreotti M, Soares NA, Costa NR. Inoculation of diazotrophic bacteria and nitrogen fertilization in topdressing in irrigated corn. Caatinga. 2016; 29:338-347. http://dx.doi.org/10.1590/198321252016v29n210rc

5. Nakao AH, Dickmann L, Souza MFP, Rodrigues R.A.F, Tarsitanto M. Análise Econômica da produção de milho safrinha em função de fontes e doses de nitrogênio e inoculação foliar com Azospirillum brasilense. Enciclopédia Biosfera. 2014; 10:278-290. Available in: http://conhecer.org.br/enciclop/2014a/AGRARIAS/Analise\%20economica.pdf

6. Kaneko FH, Sabundjian MT, Arf O, Ferreira JP, Gitti DDC, Nascimento V, Leal AJF. Análise econômica do milho em função da inoculação com Azospirillum, fontes e doses de N em cerrado de baixa altitude. Rev Bras Milho e Sorgo. 2015 14:23-37. https://doi.org/10.18512/1980-6477/rbms.v14n1p23-37

7. Boubakri H, Wahab MA, Chong J, Bertsch C, Mliki A, Soustre-Gacougnolle I. Thiamine induced resistance to Plasmopara viticola in grapevine and elicited host-defense responses, including HR like-cell death. Plant Physiol Biochem. 2012; 57:120-133. https://doi.org/10.1016/j.plaphy.2012.05.016

8. Bedour AAL, Rawia AE. Improving gladious growth, flower keeping quality by using some vitamin application. J American Sci. 2011; 7:169-174. Available in: https://www.cabdirect.org/cabdirect/abstract/20113217547

9. Kaya C, Ashraf M, Sonmez O, Tuna AL, Polat T, Aydemir S. Exogenous application of thiamin promotes growth and antioxidative defense system at initial phases of development in salt-stressed plants of two maize cultivars differing in salinity tolerance. Acta Physiol Plant. 2015; 37:1741. https://doi.org/10.1007/s11738-014-1741-3

10. Taiz L, Zeiger E, Moller IM, Murphy A. Plant physiology and development. 6th ed. USA: Sinauer Associates. 2017.

11. Cardoso MRD, Marcuzzo FFN, Barros JR. Classificação climática de KÖPPEN-GEIGER para o estado de Goiás e o Distrito Federal. Acta Geográfica. 2014; 8:40-55. Available in: http://rigeo.cprm.gov.br/jspui/handle/doc/15047

12. Santos HG, Jacomine PKT, Anjos LHC, Oliveira VÁ, Lumbreras JF, Coelho MR, Almeida JÁ, Cunha TJF, Oliveira JB. Sistema brasileiro de classificação de solos. $3^{a}$ ed. Brazil: EMBRAPA. 2013. Available in: http://livimagens.sct.embrapa.br/ amostras/00053080.pdf

13. Donagemma GK, Campos VDB, Calderano SB, Teixeira WG, Viana JHM. Manual de métodos de análise de solo. 2.ed. Brazil: EMBRAPA. 2011. Available in: https://www.infoteca.cnptia.embrapa.br/infoteca/handle/doc/990374

14. Silva DJ, Queiroz AC. Análise de alimentos: métodos químicos e biológicos. 3th ed. Brazil: UFV. 2002.

15. Martin NB, Serra R, Oliveira MDM, Angelo JA, Okawa H. Sistema integrado de custos agropecuários - CUSTAGRI. Informações Econômicas. 1998; 28:7-28. Available in: http://www.iea.sp.gov.br/ftpiea/ie/1998/tec1-0198.pdf

16. Martin NB, Serra R, Antunes JFG, Oliveira MDM, Okawa H. Custos: sistema de custo de produção agrícola. Informações Econômicas. 1994; 24:97-122. Available in: http://www.iea.sp.gov.br/ftpiea/tec1-0994.pdf

17. Dartora J, Guimarães VF, Marini D, Sander G. Adubação nitrogenada associada à inoculação com Azospirillum brasilense e Herbaspirillum seropedicae na cultura do milho. Rev Bras Eng Agricol Ambient. 2013; 10:1023-1029. Available in: https://www.researchgate.net/profile/Vandeir Guimaraes/publication/262743308 Nitrogen fertilization associated to inoculation with Azospirillum brasilense and Herbaspirillum seropedicae in the maize/links/551536eb0cf2b5d6a0e95477.pdf

18. Repke RA, Cruz SJS, Silva CJD, Figueiredo PG, Bicudo SJ. Eficiência da Azospirillum brasilense combinada com doses de nitrogênio no desenvolvimento de plantas de milho. Rev Bras Milho e Sorgo. 2013; 12:214-226. http://dx.doi. org/10.18512/1980-6477/rbms.v12n3p214-226

19. Quadros PD, Roesch LFW, Silva PRF, Vieira VM, Roehrs DD, Camargo FAO. Desempenho agronômico a campo de híbridos de milho inoculados com Azospirillum. Ceres. 2015; 61:209-218. http://dx.doi.org/10.1590/S0034$\underline{737 X 2014000200008}$

20. Santos RD, Ribeiro L, Alves A, Gomes J, Alves S, Ferreira C. Características agronômicas de variedades de milho para produção de silagem. Acta Scient. Anim Scienc. 2010; 32:367-373. http://dx.doi.org/10.4025/actascianimsci. v32i4.9299 
21. Martin JD, Carlesso R, Aires NP, Gatto JC, Dubou V, Fries HM, Scheibler RB. Irrigação deficitária para aumentar a produtividade da água na produção de silagem de milho. Irriga. 2012; 1:192-205. https://doi.org/10.15809/ irriga.2012v1n01p192

22. Moraes SD, Jobim CC, Silva MSD, Marquardt FI. Produção e composição química de híbridos de sorgo e de milho para silagem. Rev Bras saúde prod anim. 2013; 14:624-634. Available in: http://www.rbspa.ufba.br/index.php/rbspa/ article/viewArticle/2789

23. Ahn, IP, Kim S, Lee YH. Vitamin B1 functions as an activator of plant disease resistance. Plant Physiol. 2005; 138:15051515. https://doi.org/10.1104/pp.104.058693

24. Abdallah MMS, El Habbasha SF, El Sebai T. Comparison of yeast extract and Nicotinaminde foliar applications effect on quinoa plants grown under sandy soil condition. International J PharmTech Res. 2016; 9:24-32. Available in: https://www.researchgate.net/profile/Dr El Sayed El Habbasha/publication/307016945 Comparison of yeast extract and nicotinaminde foliar_applications effect on quinoa_plants_grown_under_sandy_soil_condition/ links/58ce2538a6fdcc5cccbbe963/Comparison-of-yeast-extract-and-nicotinaminde-foliar-applications-effect-onquinoa-plants-grown-under-sandy-soil-condition.pdf

25. Vendruscolo EP, Oliveira PR, Seleguini A. Aplicação de niacina ou tiamina promovem incremento no desenvolvimento de mostarda. Cultura Agronômica. 2017; 26:433-442. Available in: https://ojs.unesp.br/index. php/rculturaagronomica/article/viewFile/2382/1826

26. Vendruscolo EP, Rodrigues AHA, Martins APB, Campos LFC, Seleguini A. Tratamento de sementes com niacina ou tiamina promove o desenvolvimento e a produtividade do feijoeiro. J Agrovet Sci. 2018; 17:83-90. https://doi. org/10.5965/223811711712018083

27. Lima JA, Evangelista AR, Lopes F, Júnior EF, Nardon RF, Otsuk IP, ... Azevedo Filho JA. Composição química da silagem de plantas de milho com e sem espigas. Boletim de Indústria Animal 2007; 64:207-212. URL Available in: http://201.55.36.3/bia/index.php/bia/article/view/1227

28. Vendruscolo EP, Siqueira APS, Furtado JPM, Campos LFC, Seleguini A. Development and quality of sweet maize inoculated with diazotrophic bacteria and treated thiamine. Journal of Neotropical Agriculture. 2018; 5:45-51. https://doi.org/10.32404/rean.v5i4.2766

29. Vendruscolo EP, Siqueira APS, Rodrigues AHA, Oliveira PR, Correia SR, Seleguini A. Viabilidade econômica do cultivo de milho doce submetido à inoculação com Azospirillum brasilense e soluções de tiamina. Revista de Ciências Agrárias Amazonian Journal of Agricultural and Environmental Sciences. 2018; 61:1-7. http://dx.doi.org/10.22491/ rca.2018.2674 